\title{
The Potential Role of iNOS in Ovarian Cancer Progression and Chemoresistance
}

\author{
Michal Kielbik, Izabela Szulc-Kielbik and Magdalena Klink *(1) \\ Institute of Medical Biology, Polish Academy of Sciences, 106 Lodowa Str., 93-232 Lodz, Poland; \\ mkielbik@cbm.pan.pl (M.K.); iszulc@cbm.pan.pl (I.S.-K.) \\ * Correspondence: mklink@cbm.pan.pl; Tel.: +48422723602
}

Received: 22 March 2019; Accepted: 8 April 2019; Published: 9 April 2019

\begin{abstract}
Inducible nitric oxide synthase (iNOS), the enzyme responsible for nitric oxide (NO) production, is not present in most cells under normal conditions. The expression of its mRNA, as well as its protein synthesis and full enzymatic activity, undergoes multilevel regulation including transcriptional and posttranscriptional mechanisms, the availability of iNOS substrate and cofactors and oxygen tension. However, in various malignant diseases, such as ovarian cancer, the intracellular mechanisms controlling iNOS are dysregulated, resulting in the permanent induction of iNOS expression and activation. The present review summarizes the multistaged processes occurring in normal cells that promote NO synthesis and focuses on factors regulating iNOS expression in ovarian cancer. The possible involvement of iNOS in the chemoresistance of ovarian cancer and its potential as a prognostic/predictive factor in the course of disease development are also reviewed. According to the available yet limited data, it is difficult to draw unequivocal conclusions on the pros and cons of iNOS in ovarian cancer. Most clinical data support the hypothesis that high levels of iNOS expression in ovarian tumors are associated with a greater risk of disease relapse and patient death. However, in vitro studies with various ovarian cancer cell lines indicate a correlation between a high level of iNOS expression and sensitivity to cisplatin.
\end{abstract}

Keywords: iNOS; ovarian cancer; chemoresistance

\section{Introduction}

Inducible nitric oxide synthase (iNOS, NOS2) is one of three isoforms belonging to the family of nitric oxide synthases, which are enzymes that catalyze the production of nitric oxide (NO) from L-arginine. iNOS is a unique enzyme since the iNOS transcript and protein are not present under normal conditions in most cells. Its expression is inducible and is frequently associated with inflammation and malignant diseases. iNOS expression, enzyme activation, and subsequent NO production comprise a multistage process that undergoes complex regulation on many levels from mRNA induction to the modulation of full enzymatic activity. In the tumor environment, a number of stimuli are constantly present, and large molecular changes occur in tumor and stromal cells, resulting in the permanent induction of iNOS expression. It is well established that iNOS, along with derived NO, is an important factor in both protumor and antitumor activity, which has been proved by a number of papers available on this topic. While the importance of iNOS expression in ovarian tumors is not obvious and far from being fully understood, the present review summarizes its possible involvement in the development and growth of ovarian cancer, its association with the chemoresistance of ovarian cancer cells to platinum compounds, and its potential as a prognostic factor in the course of this disease. 


\section{2. iNOS-Structure, Enzymatic Activity and Regulation in Normal Cells}

Inducible nitric oxide synthase, which is similar to other NOS isoforms, is a homodimer with a molecular weight of approximately $130-135 \mathrm{kDa}$. It adopts a bidomain structure in which a carboxy-terminal "reductase" moiety is associated with flavin mononucleotide (FMN), flavin adenine dinucleotide (FAD) and the reduced form of nicotinamide adenine dinucleotide phosphate (NADPH), while an amino-terminal "oxygen" domain is a binding site for protoporphyrin IX (heme), tetrahydropterin $\left(\mathrm{BH}_{4}\right)$ and L-arginine. Calmodulin is noncovalently bound to the iNOS complex [1,2] (Figure 1).

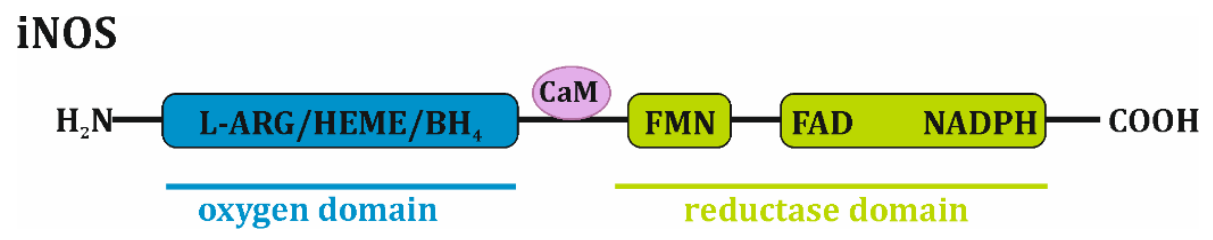

Figure 1. Domain-structured scheme of iNOS monomer. iNOS monomer is composed of oxygen domain that associates L-arginine (L-ARG), protoporphyrin IX (HEME) and tetrahydropterin (BH4), as well as reductase domain that consists of flavin mononucleotide (FMN), flavin adenine dinucleotide (FAD) and reduced form of nicotinamide adenine dinucleotide phosphate (NADPH). Calmodulin $(\mathrm{CaM})$ is noncovalently bound to the iNOS complex.

Monomeric iNOS is unable to bind the $\mathrm{BH}_{4}$ cofactor and the L-arginine substrate, thus, it cannot synthesize nitric oxide. The homodimerization process, which is required for enzyme activation, occurs in two oxygen domains, resulting in rapid conformational changes, and is dependent on the availability of $\mathrm{L}$-arginine and $\mathrm{BH}_{4}$. Moreover, the presence of heme appears to be mandatory for dimer formation and to stabilize the whole enzymatic complex. Therefore, the physiological regulation of the enzymatic activity of iNOS is primarily based on the dietary intake of L-arginine, the regulation of its transport into cells, its use by other competing biological systems, such as arginase, and the regulation of $\mathrm{BH}_{4}$ synthesis and consumption. Moreover, iNOS catalytic activity is also downregulated by NO feedback since this molecule strongly binds to the heme group. The extracellular/pharmacological blocking of iNOS activity may occur in various manners and is mainly based on the use of L-arginine derivatives that compete with the substrate, the inhibition of NADPH, the inhibition of $\mathrm{BH}_{4}$ synthesis or binding, and the inhibition of heme binding [1-6].

It is well established that NO synthesis by iNOS includes two catalytic steps. First, L-arginine is hydroxylated by molecular oxygen $\left(\mathrm{O}_{2}\right)$ and NADPH to $\mathrm{N}^{\omega}$-hydroxy-L-arginine, which is next oxidized to L-citrulline, $\mathrm{H}_{2} \mathrm{O}$ and NO. Moreover, in the absence of L-arginine and $\mathrm{BH}_{4}$, the monomeric form of iNOS reduces molecular oxygen to the superoxide anion $\left(\cdot \mathrm{O}_{2}^{-}\right)$. Thus, $\mathrm{BH}_{4}$ prevents superoxide anion synthesis via NOS. However, the reduction of oxygen to superoxide is an obligatory step during NO synthesis. The presence of both molecules $\left(\mathrm{NO}\right.$ and $\left.\cdot \mathrm{O}_{2}{ }^{-}\right)$in the reaction milieu leads to their rapid reaction to form the highly reactive radical peroxynitrite anion $\left(\mathrm{ONOO}^{-}\right)$, which is characterized by strong nitrosative and oxidative properties. Another factor controlling iNOS enzymatic activity is oxygen tension since L-arginine is converted in an $\mathrm{O}_{2}$-dependent manner $[1,4,7,8]$.

The induction of iNOS expression is a complex mechanism that undergoes multilevel control and is primarily regulated by both transcriptional and posttranscriptional mechanisms that are highly celland species-dependent. The human iNOS (NOS2) gene is 43,764 bp in size and located on chromosome 17. It encodes two transcripts: NOS2_001 and NOS2_201. The first transcript is $4176 \mathrm{nt}$ in length, encodes a protein of 1153 amino acids and is thought to be a major iNOS mRNA. The NOS2_201 transcript is $4089 \mathrm{nt}$ in length and encodes a protein of 1114 amino acids that is a splice variant of NOS2_001, but its involvement in protein synthesis is poorly recognized [5]. Extracellular signals control transcription factor activity and, consequently, iNOS gene expression and subsequent mRNA translocation. These extracellular signals are primarily pro-inflammatory cytokines (interleukin $1 \beta$, IL-1 $\beta$; interferon $\gamma$, IFN- $\gamma$; tumor necrosis factor $\alpha$, TNF- $\alpha$ ), bacterial products (lipopolysaccharide, 
LPS; lipoarabinomannan, LAM), hypoxia and oxidative stress. The promoter sequence for human iNOS contains a TATA box approximately $30 \mathrm{bp}$ from the transcription start site. Next to this are binding sites for transcription factors (NF-kB, NF-IL6), octamer factors, transcription factors induced by TNF- $\alpha$, and transcription factors induced by IFN- $\gamma$ (IRF-1, STAT-1 $\alpha)$. It is worth noting that the maximal induction of the human $i N O S$ gene is believed to occur through the binding of NF- $\mathrm{KB}$ and IRF-1 together to promoter sequences. Interestingly, a $1000 \mathrm{bp}$ fragment of the human $i N O S$ promoter showed low basal activity but no induction by cytokines. Only an iNOS promoter fragment larger than $3.8 \mathrm{~kb}$ showed any significant response to cytokines. Therefore, the promoter region relevant to cytokine-induced NF-KB/STAT- $1 \alpha$ transcriptional factors for the human $i N O S$ gene is located $3.8 \mathrm{~kb}$ upstream of the $5^{\prime}$ flanking region. A classical cytokine-induced enhancer is located between position 5.2 and 6.5. However, the notably high induction of iNOS expression (8-10-fold) was also found with the promoter fragment ranging from $7.2 \mathrm{~kb}$ to $16 \mathrm{~kb}$ [5,9-11]. Pathways that greatly contribute to transcriptional factor activation are the NF- $\mathrm{kB}$ signaling pathway, the Janus tyrosine kinase-Signal transducer and activator of transcription (JAK-STAT) pathway, and the mitogen-activated protein kinase (MAPK) pathway. Among them, NF- $\mathrm{KB}$ is a central factor for the activation or inhibition of $i N O S$ gene expression. IL- $1 \beta$, TNF- $\alpha$, and oxidative stress induce NF- $\mathrm{KB}$ activity, its translocation to the nucleus and its subsequent binding to the promoter sequence. In contrast, transforming growth factor- $\beta 1$ (TGF- $\beta 1$ ) and antioxidants inhibit NF- $\mathrm{kB}$ activity through the induction of its ubiquitin-dependent proteasomal degradation, blocking its translocation to the nucleus or enhancing $\mathrm{I}-\mathrm{KB}$ expression [5,11-13]. Interestingly, different polymorphisms in the sequence of the human iNOS promoter and their correlation with various human diseases, such as asthma or Alzheimer's disease have been described, and the relationship between specific polymorphisms and iNOS expression, activity, and NO production [12] have been reported.

The posttranscriptional regulation of human iNOS mRNA primarily involves mRNA stability and/or degradation. The $3^{\prime}$-untranslated region (3'-UTR) of human iNOS contains four AUUUA motifs and one AUUUUA motif, which are known to destabilize the mRNAs of proto-oncogenes, nuclear transcription factors, and cytokines. AU-rich elements (ARE) mediate mRNA decay primarily by the protein requirement of exosomes containing mRNA. Moreover, the TGF- $\beta$-mediated activation of nucleases acting on AU-rich sequences leads to mRNA destabilization and the inhibition of iNOS induction. Therefore, the posttranscriptional regulation of mRNA stability is dependent on the $3^{\prime}$-UTR region. Moreover, several RNA-binding proteins (HuR, AUF1, KSPR, TIAR, TTP, PTB) are involved in either the stability or the degradation of human iNOS mRNA. Using DLD-1 cells, the only human model available for this type of research, it was shown that in unstimulated cells, KSPR binds to the $3^{\prime}$-UTR of $i N O S$ mRNA and recruits exosomes to the mRNA, resulting in its rapid degradation. In cells stimulated with cytokines, TTP interacts with KSPR, preventing the binding of KSPR to mRNA, which in turn enhances HuR binding to the $3^{\prime}$-UTR iNOS sequence. The interaction of HuR with the $3^{\prime}$-UTR region increases iNOS mRNA stability and thus enhances iNOS expression. AUF1 consists of four isoforms, all of which can bind to ARE and promote iNOS mRNA degradation by competing with HuR for the same AU-rich elements. In contrast, TIAR enhances mRNA stability and increases iNOS expression [5,11,14-16].

Apart from effects on mRNA stability, another potential mechanism of iNOS posttranscriptional regulation involves short, noncoding RNAs known as microRNAs (miRNAs). It has been suggested that miRNAs block translation by the posttranscriptional repression of human iNOS. This was described in a study by Guo et al. [17], in which miR-939 was found to bind to the 3'-UTR in in vitro and in vivo models. miR-939 binding decreased cytokine-induced iNOS protein expression but did not affect its mRNA level and stability. Similarly, miR-26a and miR-146a affected the expression of iNOS protein either directly by interacting with the $3^{\prime}$-UTR (miR-26a) or indirectly by modulating the level of inflammatory cytokines (miR-146a) [18,19].

Finally, the posttranscriptional regulation of iNOS expression may involve mRNA translation and protein stability. Human cardiomyocytes express factors that can inhibit iNOS mRNA translation 
by interacting with the $5^{\prime}$ - and/or $3^{\prime}$-UTR sequences of $i N O S$ mRNA [20]. Furthermore, Felley-Bosco et al. [21] reported that the overexpression of caveolin-1 (Cav-1) in human DLD-1 cells destabilized iNOS. These data suggest that the direct interaction of Cav-1 with iNOS increased the proteasomal degradation of this enzyme.

Human iNOS expression and activity are observed in a large number of normal cells and various tissues, e.g., macrophages, neutrophils, Kupffer cells, chondrocytes, hepatocytes, and the vasculature [22]. Despite the complex, multilevel regulation of iNOS induction and activity, it is constantly upregulated in cancer cells, most likely due to vast alterations in their cellular biology.

\section{3. iNOS Expression and Regulation in Ovarian Tumors}

The constitutive overexpression of iNOS has been demonstrated in a number of tumors including breast, brain, prostate, lung, pancreas, ovarian, bladder, gastric, and colorectal tumors as well as melanoma and Kaposi's sarcoma. In most tumors, it is possible to observe the increased expression and enzymatic activity of iNOS in comparison to those in adjacent normal tissue. However, it must be noted that the cellular level and activity of iNOS strongly depend on the histological type and grade of the tumor as well as the clinical stage of the disease. Moreover, the expression of iNOS in the tumor microenvironment (tumor cells along with stromal cells) varies primarily depending on the complexity of the particular tumor environment as well as on the presence of primary or metastatic lesions. Although its precise role has still not been fully established, iNOS-derived NO has a biphasic effect on tumor-related processes, such as tumorigenesis/malignant transformation, tumor progression, angiogenesis, metastasis, and chemoresistance. This topic has been widely discussed, with vast and comprehensive knowledge available in the form of reports and reviews, therefore it was not the purpose of this paper. The most important factors that strongly influence the dichotomous effects of NO are its concentration, duration, cell cycle status, and cell redox condition and the presence of oxygen and oxygen radicals that allow the formation of reactive nitrogen species (RNS) [23-25].

iNOS expression is significantly increased in ovarian cancer compared to its expression in normal ovarian tissue or benign tumors [26]. As determined in three groups of patients suffering from ovarian cystic tumors, $88 \%$ of malignant tumors were characterized by the strongly increased expression of iNOS in comparison to that in nonneoplastic (5\%) or benign tumors (6\%) [27]. The positive expression of iNOS was observed in both epithelial cells and tumor-associated macrophages (TAM) in malignant, borderline and benign tumors [28]. The importance of iNOS-positive stromal cells (omental adipose stromal cells) in the promotion of ovarian cancer cell proliferation and their resistance to paclitaxel was shown by Salimian Rizi et al. [29]. However, it should be emphasized that similar to other tumors, both iNOS and NO play rather multifaceted roles in ovarian cancer, and despite obtainable reports in this subject, it is difficult to draw any final conclusions [30].

The expression of iNOS in tumor cells is upregulated (Figure 2) by extracellular signals, such as pro-inflammatory cytokines and hypoxia. The ovarian cancer tumor microenvironment is characterized by high levels of IL-6, IL-1, and TNF- $\alpha$, which strongly activate the JAK/STAT and MAPK signaling pathways known to be iNOS inducers [31,32]. It should be mentioned that cancer cells are characterized by the constant overexpression and overactivation of STAT3 [33], serine-threonine protein kinase (AKT) [34] and MAPK [35,36] signaling proteins, allowing them to survive, grow, proliferate and resist various chemotherapeutics. Many in vitro studies have shown that hypoxia alone or in parallel with pro-inflammatory cytokines increases the level of $i N O S$ mRNA. The main mechanism for hypoxic iNOS stimulation includes two pathways. In the first pathway, hypoxia-inducible factor (HIF), an essential factor in the cellular response to hypoxic conditions, directly binds to the hypoxia-responsive element (HRE) present in the promoter region of $i N O S$. In the second pathway, hypoxia activates NF-kB through the activation of the inhibitory $\mathrm{kB}$ kinase, leading to classical NF- $\mathrm{kB}$ signal transduction and the induction of iNOS. It is worth noting that both of these pathways are interdependent and can be altered by multiple factors (including NO) [37]. 


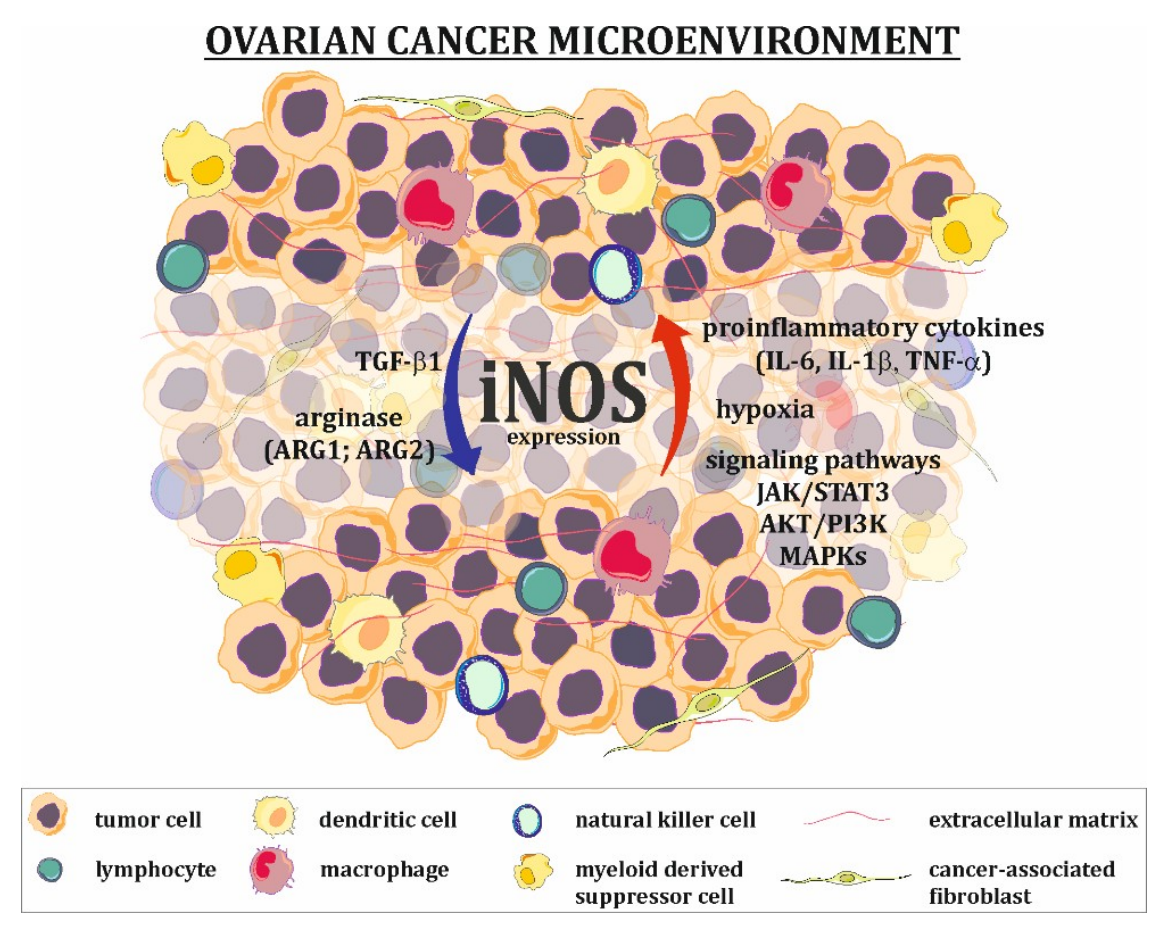

Figure 2. Regulation of iNOS expression in ovarian cancer microenvironment. Factors present in the ovarian cancer microenvironment, such as proinflammatory cytokines (IL-1 $\beta$, IL-6, TNF- $\alpha$ ), as well as hypoxia and overactivation of some signaling pathways (e.g., JAK/STAT3, AKT/PI3K, MAPKs), are responsible for upregulation of iNOS expression in tumor cells, while agents like TGF- $\beta 1$ and arginase downregulate its expression.

The agents that downregulate iNOS expression/activation are primarily arginase and TGF- $\beta 1$ (Figure 2). Arginase exists in two forms: ARG1 and ARG2. It catalyzes the conversion of arginine to ornithine and urea. One of the functions of arginase is the regulation of iNOS activity by lowering L-arginine bioavailability and the downregulation of iNOS expression, which is manifested by low levels of this amino acid [38,39]. The positive expression of TGF- $\beta 1$ in ovarian tumors, as well as in ovarian cancer cells present in ascites fluid, has been well documented [40-42]. This cytokine suppresses the expression of iNOS at the mRNA level [43].

\section{Implication of NO/RNS in the Development of Ovarian Cancer}

Tumorigenesis/carcinogenesis requires multilevel modification in somatic cells, resulting in the alternation of their morphology and functional features, such as their unlimited proliferative potential or insensitivity for apoptotic signals. The role of nitric oxide synthases, particularly iNOS, in carcinogenesis has never been directly determined, but the impact of NO, the product of these synthases, has been described in many reports. The multifaceted activities of $\mathrm{NO}$ or its derivatives, such as peroxynitrite and dinitrogen trioxide $\left(\mathrm{N}_{2} \mathrm{O}_{3}\right)$, bring about different changes in normal cells, resulting in their transformation (Figure 3). The mechanisms by which NO and/or RNS induce tumorigenesis are strongly related to oxidative/nitrosative stress and include DNA damage, the suppression of DNA repair enzymes, posttranslational modification of proteins and the formation of nitrosamines [24,25]. Genetic disorders are a high-risk factor for the development of ovarian cancer, and various signals that induce DNA injury or interference with DNA repair processes are important causes of ovarian tumorigenesis [44]. Mutations in several genes, namely, BRCA1 and BRCA2 [45], mismatch repair genes [46], BRAF, KRAS [47], and TP53 [48] are strong genetic risk factors for ovarian cancer promotion. Moreover, some authors have noted that $B R C A 1$ and $B R C A 2$ mutations are responsible for the development of almost $90 \%$ of all ovarian cancer cases [44]. 


\section{TUMORIGENESIS}

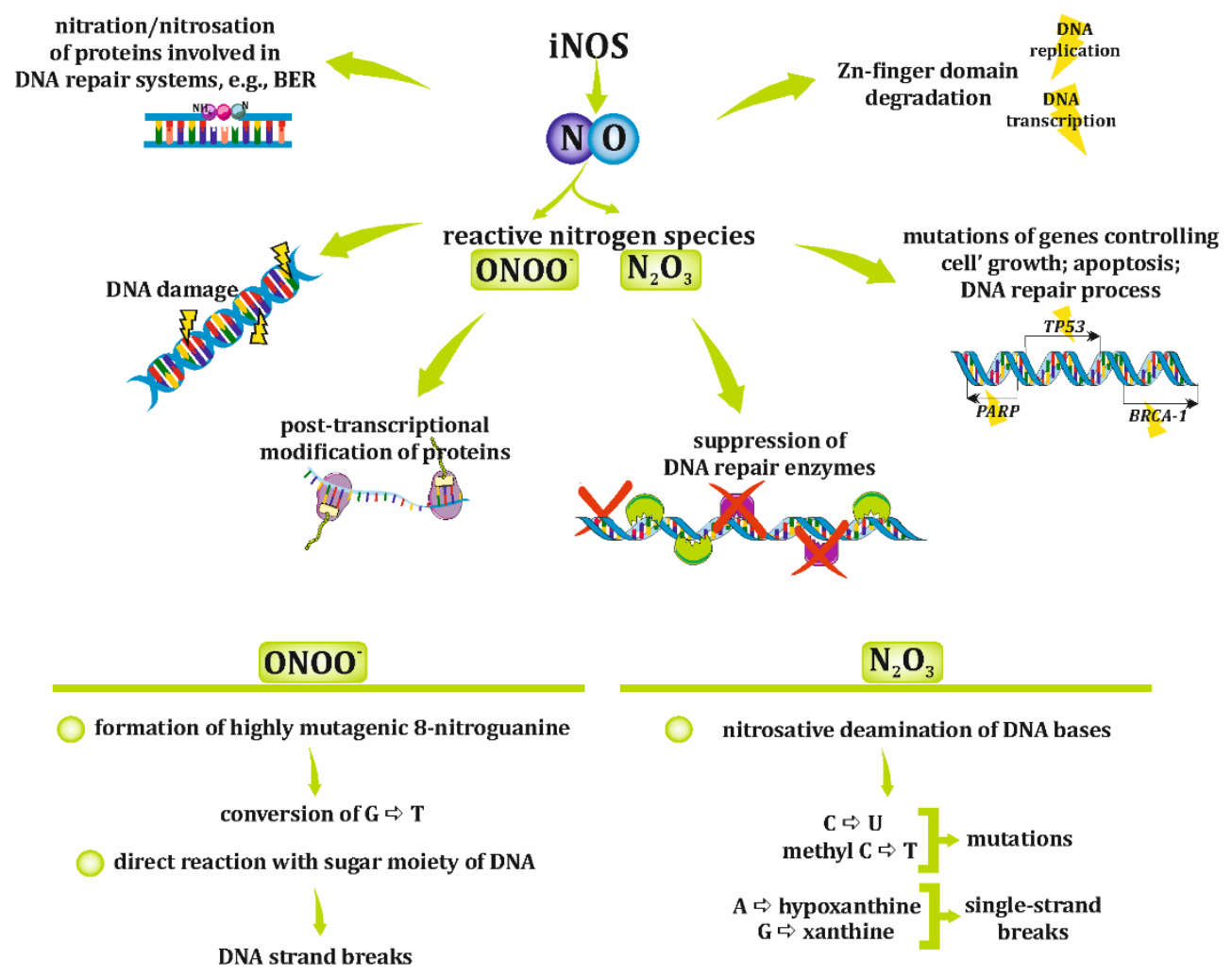

Figure 3. Role of NO and reactive nitrogen species in tumorigenesis. Although the role of iNOS has never been directly determined in carcinogenesis, the activity of its product-nitric oxide (NO)—and NO's derivatives, such as peroxynitrite $\left(\mathrm{ONOO}^{-}\right)$or dinitrogen trioxide $\left(\mathrm{N}_{2} \mathrm{O}_{3}\right)$, influence normal cells causing their transformation and inducing tumorigenesis. BER, base extinction repair system; $\mathrm{G}$, guanine; A, adenosine; $\mathrm{C}$, cytosine; $\mathrm{U}$, uracil; $\mathrm{T}$, thymidine.

The effect of NO and RNS on DNA leading to its damage, e.g., the induction of mutations, is rather well recognized and is summarized below. The exposure of DNA to NO/RNS results in the oxidation and nitration/nitrosation of the nucleic acid bases. For instance, peroxynitrite can form DNA-damaging 8-nitroguanine and 8-oxo-7,8-dihydro-2'-deoxyguanosine, which are biomarkers of inflammation-induced carcinogenesis. 8-nitroguanine is a highly mutagenic molecule able to convert guanine to tyrosine. Moreover, it was well described that $\mathrm{ONOO}^{-}$induce a DNA strand breaks due to sugar fragmentation. Whereas, the dinitrogen trioxide causes nitrosative deamination of cytosine and methyl cytosine, which results in mutations, as well as the formation of hypoxanthine and xanthine. These compounds are very unstable and cause rapid depurination and single-strand breaks. Moreover, NO/RNS degrade zinc finger domains and, thus, strongly interfere with DNA replication and transcription. Genes controlling cell growth, DNA repair processes or apoptosis (e.g., TP53, BRCA1, $B R C A 2, P A R P)$ are prime targets for NO/RNS. A strong relationship between iNOS activity and the G:C to A:T mutation in TP53 resulting in the loss of p53 suppressor activity was reported in various carcinomas, e.g., colon, gastric, head and neck, and ovarian cancers [22,24,48-51].

Furthermore, RNS strongly participate in the nitration/nitrosation of DNA repair proteins. The formation of nitro adducts on aromatic groups, such as tyrosyl residues, and RNS attacks on nucleophilic sites, such as cysteinyl thiolates, are critical for protein function. The best-known targets for RNS are proteins involved in the base excision repair (BER) pathway. The inhibition of DNA repair protein activity makes cells more vulnerable to various carcinogenic mediators, e.g., alkylating agents and RNS [24,52,53]. 
However, it must be emphasized that the origin and causes of ovarian tumors still remain under debate. Thus, the NO/ effect of NO/RNS on DNA should be considered only as one of many possible mechanisms.

\section{Can iNOS Expression be a Prognostic Factor in Ovarian Cancer?}

Prognostic markers, which are well established in clinical practice, are mainly clinicopathologic in nature and include evaluation of the histopathological type, the stage of disease, the presence of high-volume ascites, the age at diagnosis and the process of surgical debulking [54-56]. Additionally, characteristic features of cancer cells, such as BRCA gene mutation [57], the surface molecule expression of EpCAM [58], and the protein expression of PTEN, HIF, and VEGF [59], are also useful as prognostic markers. Nevertheless, their effectiveness and accuracy are still not satisfactory to stop searching for new, more appropriate factors. Available reports regarding iNOS expression as a potential prognostic factor in ovarian cancer patients are rather controversial, and it is difficult to draw a final conclusion. The published data are conflicting and show both potential and the lack of prognostic value of iNOS expression. The following paragraphs present a short review of selected reports (published over the last 15 years) describing whether iNOS expression can be considered an important marker (Table 1).

Table 1. Possibility of using iNOS expression in ovarian tumors as prognostic/prediction factor.

\begin{tabular}{|c|c|}
\hline Votes For & Ref. \\
\hline $\begin{array}{l}\text { iNOS expression in ovarian serous carcinoma (FIGO III) is an independent predictor of disease } \\
\text { relapse and patients death }\end{array}$ & [60] \\
\hline High iNOS expression in type II ovarian cancer is a poor prognostic factor & [61] \\
\hline iNOS-negative ovarian serous carcinoma indicate longer progression-free survival & [62] \\
\hline High iNOS expression in ovarian serous and mucinous carcinoma is a poor prognostic factor & [63] \\
\hline $\begin{array}{l}\text { High iNOS expression in ovarian serous and mucinous carcinoma is associated with more } \\
\text { aggressive phenotype of tumor and poor survival outcome }\end{array}$ & [64] \\
\hline \multicolumn{2}{|l|}{ Votes Against } \\
\hline iNOS expression does not correlate with FIGO and grade and has no prognostic value & [65] \\
\hline iNOS expression has no impact on patients survival & [66] \\
\hline iNOS expression has no impact on FIGO, grade, response to chemotherapy or patients survival & [67] \\
\hline
\end{tabular}

\subsection{Votes For}

Raspollini et al. [60] studied the expression of iNOS (immunohistochemistry assay) in specimens obtained by surgical resection from 78 patients with stage III (FIGO classification) ovarian serous carcinoma with a low grade of differentiation (G3). In 50 patients $(60 \%)$, positive immunostaining for iNOS was observed. Moreover, the authors proved that iNOS expression was significantly associated with the risk of disease relapse and patient death. In iNOS-positive patients, a disease-free survival period lower than 12 months accounted for $80 \%$ of patient outcomes, while in iNOS-negative patients, it accounted for $42 \%$. The authors concluded that iNOS expression in ovarian tumors can be a significant independent predictor of disease relapse and patient survival.

The results of other studies [61] also clearly indicated the involvement of iNOS in poor patient survival. A total of 213 ovarian cancer patients enrolled in the studies were divided into two groups according to histopathology: type I (82 cases) and type II (131 cases). iNOS expression (immunohistochemistry) was observed in both groups, and there was significantly higher iNOS expression in patients with type II ovarian cancer compared to that in patients with type I ovarian cancer. Moreover, women with type II ovarian cancer had a poorer median survival time (60 months) than those with type I tumors (141 months). 
Engels et al. [62] reported that iNOS is a prognostic marker for the clinical outcome of serous ovarian cancer patients. This study included a homogenous group of 112 patients with serous adenocarcinoma of the ovary. iNOS-negative tumors were characterized by improved progression-free survival time. Hence, pretherapeutic assessment of the iNOS level as a predictive factor for complete tumor resection might be of clinical value.

Other studies [63] tested the expression of iNOS in specimens from 90 patients categorized as benign, borderline, and malignant tumors by immunohistochemistry. As described, the highest expression of iNOS was observed in serous and mucinous malignant tumors, which was significantly higher than its expression in serous and mucinous benign tumors. The authors hypothesized that the upregulation of iNOS indicated its involvement in disease progression. Moreover, the enhanced expression of iNOS in less differentiated cancers may indicate its association with poor prognosis for patients with this type of tumor.

A positive correlation between high iNOS expression with poorly differentiated, advanced clinical stage (FIGO III/IV) serous ovarian carcinoma was shown by Li et al. [64]. The data were obtained based on an analysis of specimens from 150 ovarian tumor patients. iNOS overexpression plays an important role in the regulation of glycolysis, and the data show that iNOS-induced NO promotes this process. As the authors concluded, high levels of iNOS expression promote more aggressive phenotypes of ovarian tumors and are associated with poor survival outcome.

\subsection{Votes Against}

Very interesting and widely ranging studies were completed by Anttila et al. [65]. iNOS expression was tested in specimens from 301 epithelial ovarian cancer patients with consideration to FIGO stage, histopathological type, and histological grade. iNOS expression was correlated with histological subtype, and high levels of iNOS expression were only found in mucinous tumors. The FIGO and grade classifications, however, were not significant. Moreover, iNOS expression and its intensity had no prognostic value in any group of patients.

In studies published by Ozel et al. [66] iNOS expression along with angiogenesis microvessel density (MVD) were evaluated in specimens from 100 patients suffering ovarian carcinomas (various histopathological types). No correlation was found between iNOS expression and MVD, and iNOS expression had no impact on the survival of the patients.

Martins Filho et al. [67] evaluated 40 patients with ovarian cancer who underwent surgical treatment. Immunohistochemistry for iNOS and various cytokines was performed. The authors presented the complex relationship between iNOS, the immune response and tumor progression, indicating that there is no relationship between iNOS expression and the clinical stage of disease (FIGO), histological grade, response to chemotherapy, and disease-free survival $\leq 24$ months.

\subsection{NO Correct Answer}

The examples presented above clearly show that the role of iNOS in ovarian cancer is not straightforward. Moreover, it is difficult to clearly see the whole picture, since all available information on this topic is rather modest due to the limited number of papers. Additionally, the lack of a sufficiently large group of patient samples, as well as the high histopathological variability of ovarian cancer, are another huge limitation in drawing unambiguous conclusions.

\section{6. iNOS Expression Versus Chemoresistance in Ovarian Cancer Cells}

The conventional therapy for ovarian cancer involves cytoreductive surgery of the tumor followed by the administration of chemotherapeutics. The accepted standard first-line treatment includes a combination of a platinum-containing agent (cisplatin, carboplatin) and a taxane (paclitaxel, docetaxel). The initial response to chemotherapy is promising, with the majority of patients $(70-80 \%)$ responding positively. Nevertheless, depending on the stage of the disease, ovarian cancer recurs, with recurrence in up to $30 \%$ of patients with early-stage ovarian cancer to up to $85 \%$ of patients with an advanced 
stage of disease for 6-24 months after chemotherapy. Most relapse patients have acquired platinum resistance during repeated chemotherapy cycles. Moreover, in the heterogenic tumor microenvironment, some primary platinum-resistant cells are also present. It is accepted that prognosis for the five-year survival rate for patients with an advanced stage of the disease is rather poor and reaches approximately only $20 \%-35 \%[68,69]$.

The development of platinum resistance in ovarian cancer cells is a complex process. The molecular mechanisms implicated in this phenomenon include increased DNA repair, increased levels and activity of efflux pump proteins, the overactivation of signaling pathways (JAK/STAT, PI3K/AKT, MAPK) involved in cell survival, and cisplatin inactivation through the intracellular thiol glutathione $[69,70]$. iNOS-derived NO and its RNS derivatives can be implicated in all these processes in both ways, either enhancing or decreasing the platinum resistance. Lowering ovarian cancer chemoresistance by NO/RNS involves, among others competition with cisplatin for the glutathione [71], decreasing activity of STAT3 and AKT signaling proteins [48,72], induction of DNA damage [50-52], inhibition of DNA repair protein activity $[24,52,53]$, induction of apoptosis through, e.g., activation of p53 pathway, down-regulation of anti-apoptotic proteins or activation of Fas receptor $[25,73]$. On the other hand, $\mathrm{NO} / \mathrm{RNS}$ can enhance drug resistance of cancer cells by various mechanisms, such as inhibition of apoptosis through, e.g., inhibition of caspase activity or increase in Bcl-2 expression [22], up-regulation of activity of proteins repairing DNA strand breaks [74] or lowering death receptors (CD95) exposure on cell surface by cGMP-dependent phosphorylation of syntaxin 4 [75] [Figure 4].

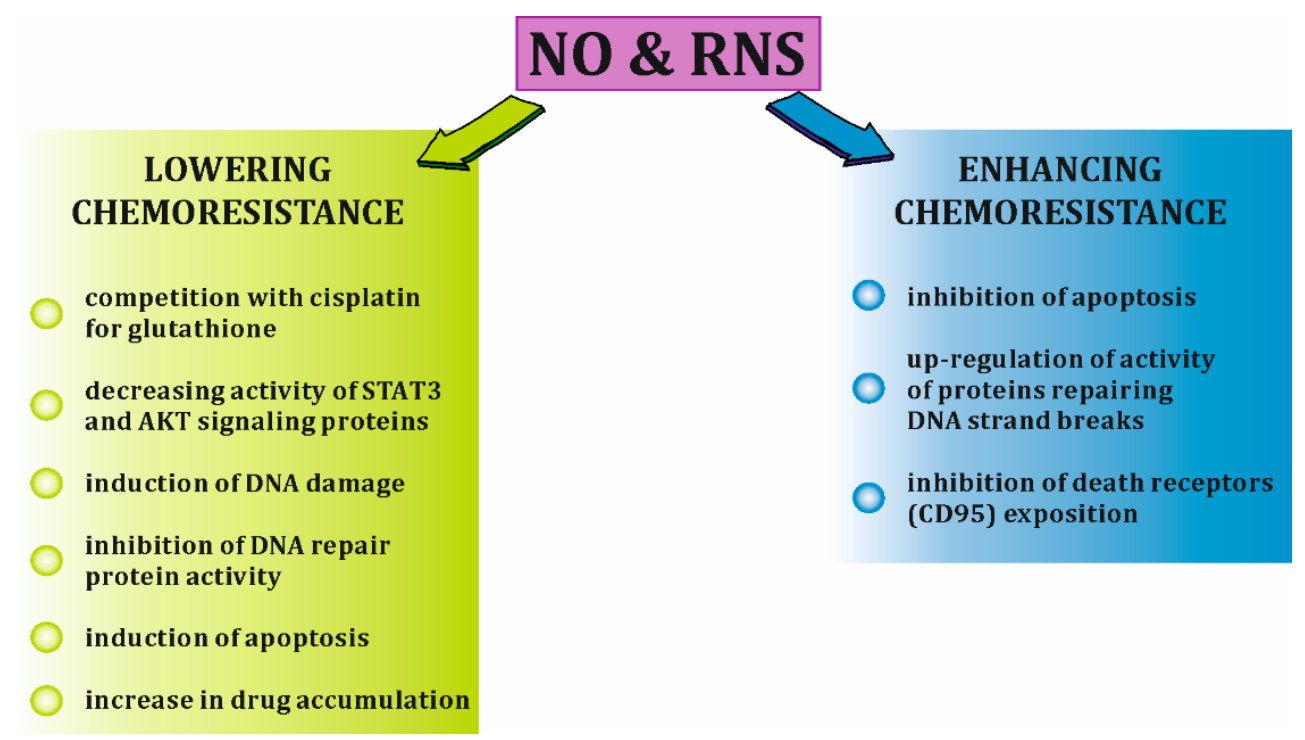

Figure 4. Selected mechanisms of NO/RNS impact on cisplatin resistance in cancer cells. RNS, reactive nitrogen species; STAT3, signal transducer and activator or transcription pathways 3; AKT, serine-threonine protein kinase.

Since chemoresistance in ovarian cancer is a serious clinical problem that has not been successfully overcome, there is an urgent need for a better understanding of its molecular basis. Thus, iNOS expression and activity and how they correlate with resistance to cisplatin have been the focus of many studies. A brief insight into the data available on this issue is presented below (Table 2).

In vitro studies on various ovarian cancer cell lines have delivered controversial data. For example, the cytosolic level of iNOS was significantly higher in the cisplatin-sensitive ovarian cancer cell line OV2008 than in resistant C13* cells, which suggests the association of cisplatin resistance with low iNOS content. Moreover, cisplatin significantly increased the iNOS level, but only in OV2008 cells. Interestingly, studies using a specific iNOS inhibitor clearly indicate that this protein participates in cisplatin-induced apoptosis in sensitive cells. The pro-apoptotic effect of iNOS is dependent on the accumulation of a high level of $\mathrm{p} 53$, which is caused by NO production [76]. A similar relationship 
between high basal iNOS expression and sensitivity to cisplatin was observed in SKOV-3 cells by Yu et al. [77]. This drug enhanced iNOS protein levels more efficiently in sensitive SKOV-3 cells in a dose-dependent manner than in resistant SKOV-3/DDP cells. Moreover, the increase in iNOS expression by using TAT-IDPs in SKOV-3/DDP cells resulted in increased apoptosis. In contrast, another study demonstrated that the cisplatin-resistant ovarian cancer cell line MDAH2774 was characterized by increased $i N O S$ mRNA levels compared to the levels in its sensitive counterpart. However, yet another study showed that resistant and sensitive SKOV-3 cells manifested similar levels of $i N O S$ mRNA [78]. iNOS-induced NO production was also observed in cisplatin-resistant ovarian cancer cells. Moreover, these cells are characterized by an enhanced level of glutathione, which is related to lower cisplatin efficacy, as high levels of this thiol are known to inactivate various cytotoxic agents [71]. Taken together, many reports support the argument that iNOS-expressing ovarian tumor cells are more sensitive to cisplatin chemotherapy and more easily undergo apoptosis than cells that do not express iNOS.

Table 2. Correlation of iNOS expression and/or NO production with resistance of ovarian cancer cell lines to cisplatin.

\begin{tabular}{|c|c|c|c|c|}
\hline \multicolumn{2}{|c|}{ Basal iNOS Expression, NO Production } & \multicolumn{2}{|c|}{ Cisplatin-Induced iNOS Expression, NO Production } & \multirow{2}{*}{ Ref. } \\
\hline $\begin{array}{c}\text { Cisplatin Resistant } \\
\text { Ovarian Cancer Cell Line }\end{array}$ & $\begin{array}{c}\text { Cisplatin Sensitive } \\
\text { Ovarian Cancer Cell Lines }\end{array}$ & $\begin{array}{c}\text { Cisplatin Resistant } \\
\text { Ovarian Cancer Cell Line }\end{array}$ & $\begin{array}{c}\text { Cisplatin Sensitive } \\
\text { Ovarian Cancer Cell Lines }\end{array}$ & \\
\hline Low protein level & High protein level & No induction of iNOS & High induction of iNOS & [76] \\
\hline Low protein level & High protein level & Low induction of iNOS & High induction of iNOS & [77] \\
\hline High mRNA level & Low mRNA level & $\mathrm{Nd}$ & nd & [78] \\
\hline Low mRNA level & Low mRNA level & $\mathrm{Nd}$ & nd & [78] \\
\hline High NO production & Low NO production & $\mathrm{Nd}$ & nd & [71] \\
\hline
\end{tabular}

\section{Targeting of iNOS in Ovarian Cancer}

Since iNOS and the NO it produces have a dual nature and express both pro- and antitumor activity, it is probable that iNOS inhibitors or enhancers can be both beneficial and detrimental to ovarian cancer cell activity and survival. However, to date, few studies have explored the role of iNOS level manipulation in ovarian cancer. Thus, more research regarding the importance of this enzyme as a therapeutic target for ovarian cancer treatment is strongly needed. In a published report, the culture of SKOV-3 and MDAH2774 ovarian cancer cells with L-NAME (an L-arginine analog) significantly reduced the ability of cells to produce vascular endothelial growth factor (VEGF) and completely blocked their capacity for angiogenesis, in the in vitro angiogenesis assay. Therefore, the authors noted the positive effect of iNOS inhibition on blocking the metastatic potential of ovarian cancer cells. It should be noticed that the action of L-NAME was related to the decrease of the NO level, which is known to up-regulate the strongly pro-angiogenic factors IL-8 and VEGF-A [79]. Another study showed that a lack of iNOS activity is worse for cancer cells. The addition of $1400 \mathrm{~W}$, an iNOS inhibitor, to OVCAR-3 and Caov-3 ovarian cancer cell cultures or their treatment with NOS2 siRNA significantly reduced cell growth. Moreover, targeting iNOS also had a positive effect on the immune cell content in the tumor environment, since NOS2 siRNA decreased the number of M2-type TAM in OVCAR-3 and Caov-3 xenografts [80]. Similarly, silencing $i N O S$ gene expression in epithelial the ovarian cancer cell lines MDAH2774 and SKOV-3 resulted in increased caspase-3 activity and a significant increase in cell apoptosis assessed by TUNEL. What is also interesting iNOS expression was in strict correlation with myeloperoxidase (MPO) expression, and silencing MPO gene also resulted in significant induction of ovarian cancer cells apoptosis [81]. On the other hand, it should also be mentioned that the beneficial effect of iNOS expression in tumor relapse was also described. Studies using a murine ovarian carcinoma model showed that IFN- $\gamma$ gene therapy (liposomal IFN- $\gamma$ gene) together with cisplatin-induced high levels of NO in ascites and kept the mice alive. In contrast, iNOS KO mice treated in the same way showed no NO in ascites and died in the course of treatment [82]. A different study also showed that iNOS-expressing micro-encapsulated cells significantly inhibited tumor mass (induced by SKOV-3) in mice [83]. Subsequent studies confirmed the efficacy of the induced activity of iNOS in tumor treatment. The tumor burden (mouse ovarian teratoma) was decreased, and the 
survival of mice was extended in the group of animals treated with IFN- $\beta$, which was accompanied by the increased level of NO. Moreover, the increased number of natural killer cells and macrophages in the tumor microenvironment of IFN- $\beta$-treated animals was observed [84]. In another study authors used two ovarian carcinoma cell lines, one parental ES2 cells, and one DLX4-overexpressing ES2 cells. They demonstrated that DLX4 (a homeoprotein) strongly stimulated the activity of STAT1 which next induced iNOS expression and high NO production. Whereas NO was responsible for the stimulation of ovarian cancer cells to high VEGF-A production. The authors also gave proof in the in vivo xenograft model that DLX4-related iNOS expression stimulated ovarian tumor angiogenesis. The key mechanism by which NO promote angiogenesis is the induction of VEGF-A production [85] (Table 3).

Table 3. Summary of the beneficial and detrimental effects of iNOS targeting in ovarian cancer.

\begin{tabular}{|c|c|c|c|}
\hline Ovarian Cancer Model & Treatment & Effect & Ref. \\
\hline \multicolumn{4}{|c|}{ iNOS Inhibition } \\
\hline Ovarian cancer cell lines & L-NAME -NOS inhibitor & Reduction of VEGF production & [79] \\
\hline Ovarian cancer cell lines & $\begin{array}{c}\text { 1400W- iNOS inhibitor } \\
\text { iNOS siRNA }\end{array}$ & Inhibition of cell growth & [80] \\
\hline Ovarian cancer cell lines & iNOS siRNA & $\begin{array}{l}\text { Increased activity of caspase } 3 \\
\text { Induction of cell apoptosis }\end{array}$ & [81] \\
\hline Xenograft model & iNOS SiRNA & Decrease in number of M2-type of TAM in tumor & [80] \\
\hline \multicolumn{4}{|c|}{ iNOS Induction } \\
\hline Murine ovarian carcinoma & IFN- $\gamma+$ cisplatin & $\begin{array}{l}\text { High level of NO in ascites } \\
\text { Enhanced survival of mice }\end{array}$ & [82] \\
\hline Murine ovarian carcinoma & $\begin{array}{l}\text { iNOS-expressed } \\
\text { micro-encapsulated cells }\end{array}$ & Inhibition of tumor growth & [83] \\
\hline Mouse ovarian teratoma & IFN- $\beta$ & $\begin{array}{l}\text { Inhibition of tumor growth } \\
\text { Enhanced survival of mice }\end{array}$ & [84] \\
\hline Ovarian cancer cell lines & DLX4 & $\begin{array}{l}\text { Stimulation of STAT1 activity } \\
\text { Stimulation of VEGF-A production }\end{array}$ & [85] \\
\hline Xenograft model & DLX4 & Stimulation of tumor angiogenesis & [85] \\
\hline
\end{tabular}

Although studies cited above clearly indicated that targeting iNOS therapy is promising in the treatment of ovarian cancer, available data on this topic are still scarce, and it is difficult to draw a final conclusion. To our best knowledge, there are no data about the clinical use of iNOS inhibitors/enhancers in ovarian cancer patients. The only available insight in this matter involves in vitro studies with cell lines and in vivo studies using animal models.

\section{Concluding Remarks}

iNOS expression is easily detected in ovarian tumor specimens and in various ovarian cancer cell lines cultured in vitro. Although the constant overexpression of this enzyme is often observed in this type of cancer, the role of iNOS in ovarian cancer growth, survival and resistance to platinum compounds is not clear. The multiple pros and cons of iNOS expression described in the available literature so far do not allow us to draw straightforward conclusions regarding the role of iNOS in ovarian tumors. While most reports point to the association of high levels of iNOS expression in ovarian tumors with the risk of disease relapse and patient death, some reports indicate that ovarian tumor cells with high iNOS expression are more sensitive to cisplatin treatment. The inhibition or induction of iNOS as a novel approach to ovarian cancer treatment also delivers conflicting results. Further studies on a large group of patients including a study on the histopathological variability of ovarian cancer and the determination of the molecular interplay between iNOS and various cancer cell-related signaling pathways are necessary to resolve the question of whether iNOS is beneficial or detrimental in ovarian cancer.

Author Contributions: M.K. (Mgdalena Klink): conceptualization, data acquisition, drafting of the manuscript, critical revision of the manuscript and approval of the article; M.K. (Michal Kielbik): data acquisition, drafting of the manuscript, critical revision of the manuscript; I.S.-K.: drafting of the manuscript, conceptualization and preparation of figures, critical revision of the manuscript. 
Funding: This research received no external funding.

Conflicts of Interest: The authors declare no conflict of interest.

\section{Abbreviations}

$\begin{array}{ll}\mathrm{O}_{2}{ }^{-} & \text {superoxide anion } \\ 3^{\prime}-\mathrm{UTR} & 3^{\prime} \text {-untranslated region } \\ \mathrm{AKT} & \text { serine-threonine protein kinase } \\ \mathrm{ARE} & \text { AU-rich element } \\ \mathrm{BH}_{4} & \text { tetrahydropterin } \\ \text { FAD } & \text { flavin adenine dinucleotide } \\ \text { FIGO } & \text { International Federation of Gynecology and Obstetrics } \\ \text { FMN } & \text { flavin mononucleotide } \\ \text { HIF } & \text { hypoxia-inducible factor } \\ \text { IFN- } \gamma & \text { interferon- } \gamma \\ \text { IL } & \text { interleukin } \\ \text { iNOS } & \text { inducible nitric oxide synthase } \\ \text { JAK } & \text { Janus tyrosine kinase } \\ \text { MAPK } & \text { mitogen-activated protein kinase } \\ \text { miRNA } & \text { microRNA } \\ \text { NADPH } & \text { reduced form of nicotinamide adenine dinucleotide phosphate } \\ \text { NO } & \text { nitric oxide } \\ \text { ONOO- } & \text { peroxynitrite anion } \\ \text { RNS } & \text { reactive nitrogen species } \\ \text { STAT } & \text { signal transducer and activator of transcription } \\ \text { TGF- } \beta 1 & \text { transforming growth factor- } \beta 1 \\ \text { TNF- } \alpha & \text { tumor necrosis factor- } \alpha\end{array}$

\section{References}

1. Alderton, W.K.; Cooper, C.E.; Knowles, R.G. Nitric oxide synthases: Structure, function and inhibition. Biochem. J. 2001, 357, 593-615. [CrossRef] [PubMed]

2. Groves, J.T.; Wang, C.C. Nitric oxide synthase: Models and mechanisms. Curr. Opin. Chem. Biol. 2000, 4, 687-695. [CrossRef]

3. Kröncke, K.D.; Fehsel, K.; Kolb-Bachofen, V. Inducible nitric oxide synthase and its product nitric oxide, a small molecule with complex biological activities. Biol. Chem. Hoppe Seyler 1995, 376, 327-343. [CrossRef]

4. Aktan, F. iNOS-mediated nitric oxide production and its regulation. Life Sci. 2004, 75, 639-653. [CrossRef] [PubMed]

5. Pautz, A.; Art, J.; Hahn, S.; Nowag, S.; Voss, C.; Kleinert, H. Regulation of the expression of inducible nitric oxide synthase. In Nitric Oxide; Academic Press: Cambridge, MA, USA, 2010; Volume 23, pp. 75-93.

6. Keshet, R.; Erez, A. Arginine and the metabolic regulation of nitric oxide synthesis in cancer. Dis. Model. Mech. 2018, 11, dmm033332. [CrossRef] [PubMed]

7. Xia, Y. Superoxide generation from nitric oxide synthases. Antioxid. Redox Signal. 2007, 9, 1773-1778. [CrossRef]

8. Bogdan, C. Nitric oxide synthase in innate and adaptive immunity: An update. Trends Immunol. 2015, 36, 161-178. [CrossRef] [PubMed]

9. Guo, Z.; Geller, D.A. microRNA and human inducible nitric oxide synthase. In Vitamins E Hormones; Academic Press: Cambridge, MA, USA, 2014; Volume 96, pp. 19-27.

10. Lirk, P.; Hoffmann, G.; Rieder, J. Inducible nitric oxide synthase-time for reappraisal. Curr. Drug Targets Inflamm. Allergy 2002, 1, 89-108. [CrossRef] [PubMed]

11. Kleinert, H.; Pautz, A.; Linker, K.; Schwarz, P.M. Regulation of the expression of inducible nitric oxide synthase. Eur. J. Pharmacol. 2004, 500, 255-266. [CrossRef] [PubMed]

12. Kleinert, H.; Schwarz, P.M.; Förstermann, U. Regulation of the expression of inducible nitric oxide synthase. Biol. Chem. 2003, 384, 1343-1364. [CrossRef] [PubMed] 
13. Lowenstein, C.J.; Padalko, E. iNOS (NOS2) at a glance. J. Cell Sci. 2004, 117, 2865-2867. [CrossRef] [PubMed]

14. Pautz, A.; Linker, K.; Altenhöfer, S.; Heil, S.; Schmidt, N.; Art, J.; Knauer, S.; Stauber, R.; Sadri, N.; Pont, A.; et al. Similar regulation of human inducible nitric-oxide synthase expression by different isoforms of the RNA-binding protein AUF1. J. Biol. Chem. 2009, 284, 2755-2766. [CrossRef] [PubMed]

15. Rodriguez-Pascual, F.; Hausding, M.; Ihrig-Biedert, I.; Furneaux, H.; Levy, A.P.; Förstermann, U.; Kleinert, H. Complex contribution of the $3^{\prime}$-untranslated region to the expressional regulation of the human inducible nitric-oxide synthase gene. Involvement of the RNA-binding protein HuR. J. Biol. Chem. 2000, 275, 26040-26049. [CrossRef]

16. Linker, K.; Pautz, A.; Fechir, M.; Hubrich, T.; Greeve, J.; Kleinert, H. Involvement of KSRP in the post-transcriptional regulation of human iNOS expression-complex interplay of KSRP with TTP and HuR. Nucleic Acids Res. 2005, 33, 4813-4827. [CrossRef]

17. Guo, Z.; Shao, L.; Zheng, L.; Du, Q.; Li, P.; John, B.; Geller, D.A. miRNA-939 regulates human inducible nitric oxide synthase posttranscriptional gene expression in human hepatocytes. Proc. Natl. Acad. Sci. USA 2012, 109, 5826-5831. [CrossRef]

18. Li, X.; Gibson, G.; Kim, J.-S.; Kroin, J.; Xu, S.; van Wijnen, A.J.; Im, H.-J. MicroRNA-146a is linked to pain-related pathophysiology of osteoarthritis. Gene 2011, 480, 34-41. [CrossRef]

19. Zhu, H.; Vishwamitra, D.; Curry, C.V.; Manshouri, R.; Diao, L.; Khan, A.; Amin, H.M. NPM-ALK up-regulates iNOS expression through a STAT3/microRNA-26a-dependent mechanism. J. Pathol. 2013, 230, 82-94. [CrossRef]

20. Luss, H.; Li, R.K.; Shapiro, R.A.; Tzeng, E.; McGowan, F.X.; Yoneyama, T.; Hatakeyama, K.; Geller, D.A.; Mickle, D.A.; Simmons, R.L.; et al. Dedifferentiated human ventricular cardiac myocytes express inducible nitric oxide synthase mRNA but not protein in response to IL-1, TNF, IFNgamma, and LPS. J. Mol. Cell. Cardiol. 1997, 29, 1153-1165. [CrossRef] [PubMed]

21. Felley-Bosco, E.; Bender, F.; Quest, A.F.G. Caveolin-1-mediated post-transcriptional regulation of inducible nitric oxide synthase in human colon carcinoma cells. Biol. Res. 2002, 35, 169-176. [CrossRef]

22. Choudhari, S.K.; Chaudhary, M.; Bagde, S.; Gadbail, A.R.; Joshi, V. Nitric oxide and cancer: A review. World J. Surg. Oncol. 2013, 11, 118. [CrossRef]

23. Bian, K.; Ghassemi, F.; Sotolongo, A.; Siu, A.; Shauger, L.; Kots, A.; Murad, F. NOS-2 signaling and cancer therapy. IUBMB Life 2012, 64, 676-683. [CrossRef]

24. Lechner, M.; Lirk, P.; Rieder, J. Inducible nitric oxide synthase (iNOS) in tumor biology: The two sides of the same coin. Semin. Cancer Biol. 2005, 15, 277-289. [CrossRef]

25. Burke, A.J.; Sullivan, F.J.; Giles, F.J.; Glynn, S.A. The yin and yang of nitric oxide in cancer progression. Carcinogenesis 2013, 34, 503-512. [CrossRef]

26. Burke, A.J.; Garrido, P.; Johnson, C.; Sullivan, F.J.; Glynn, S.A. Inflammation and Nitrosative Stress Effects in Ovarian and Prostate Pathology and Carcinogenesis. Antioxid. Redox Signal. 2017, 26, 1078-1090. [CrossRef]

27. Nomelini, R.S.; de Abreu Ribeiro, L.C.; Tavares-Murta, B.M.; Adad, S.J.; Murta, E.F.C. Production of nitric oxide and expression of inducible nitric oxide synthase in ovarian cystic tumors. Mediat. Inflamm. 2008, 2008, 186584. [CrossRef]

28. Klimp, A.H.; Hollema, H.; Kempinga, C.; van der Zee, A.G.; de Vries, E.G.; Daemen, T. Expression of cyclooxygenase-2 and inducible nitric oxide synthase in human ovarian tumors and tumor-associated macrophages. Cancer Res. 2001, 61, 7305-7309.

29. Salimian Rizi, B.; Caneba, C.; Nowicka, A.; Nabiyar, A.W.; Liu, X.; Chen, K.; Klopp, A.; Nagrath, D. Nitric oxide mediates metabolic coupling of omentum-derived adipose stroma to ovarian and endometrial cancer cells. Cancer Res. 2015, 75, 456-471. [CrossRef]

30. El-Sehemy, A.; Postovit, L.-M.; Fu, Y. Nitric oxide signaling in human ovarian cancer: A potential therapeutic target. Nitric Oxide Biol. Chem. 2016, 54, 30-37. [CrossRef]

31. Macciò, A.; Madeddu, C. Inflammation and ovarian cancer. Cytokine 2012, 58, 133-147. [CrossRef]

32. Kulbe, H.; Chakravarty, P.; Leinster, D.A.; Charles, K.A.; Kwong, J.; Thompson, R.G.; Coward, J.I.; Schioppa, T.; Robinson, S.C.; Gallagher, W.M.; et al. A dynamic inflammatory cytokine network in the human ovarian cancer microenvironment. Cancer Res. 2012, 72, 66-75. [CrossRef]

33. Yu, H.; Kortylewski, M.; Pardoll, D. Crosstalk between cancer and immune cells: Role of STAT3 in the tumour microenvironment. Nat. Rev. Immunol. 2007, 7, 41-51. [CrossRef] [PubMed] 
34. Paez, J.; Sellers, W.R. PI3K/PTEN/AKT pathway. A critical mediator of oncogenic signaling. Cancer Treat Res. 2003, 115, 145-167. [PubMed]

35. Burotto, M.; Chiou, V.L.; Lee, J.-M.; Kohn, E.C. The MAPK pathway across different malignancies: A new perspective. Cancer 2014, 120, 3446-3456. [CrossRef]

36. McCubrey, J.A.; Steelman, L.S.; Chappell, W.H.; Abrams, S.L.; Wong, E.W.T.; Chang, F.; Lehmann, B.; Terrian, D.M.; Milella, M.; Tafuri, A.; et al. Roles of the Raf/MEK/ERK pathway in cell growth, malignant transformation and drug resistance. Biochim. Biophys. Acta 2007, 1773, 1263-1284. [CrossRef] [PubMed]

37. Robinson, M.A.; Baumgardner, J.E.; Otto, C.M. Oxygen-dependent regulation of nitric oxide production by inducible nitric oxide synthase. Free Radic. Biol. Med. 2011, 51, 1952-1965. [CrossRef]

38. Timosenko, E.; Hadjinicolaou, A.V.; Cerundolo, V. Modulation of cancer-specific immune responses by amino acid degrading enzymes. Immunotherapy 2017, 9, 83-97. [CrossRef]

39. Molinier-Frenkel, V.; Castellano, F. Immunosuppressive enzymes in the tumor microenvironment. FEBS Lett. 2017, 591, 3135-3157. [CrossRef]

40. Abendstein, B.; Stadlmann, S.; Knabbe, C.; Buck, M.; Müller-Holzner, E.; Zeimet, A.G.; Marth, C.; Obrist, P.; Krugmann, J.; Offner, F.A. Regulation of transforming growth factor-beta secretion by human peritoneal mesothelial and ovarian carcinoma cells. Cytokine 2000, 12, 1115-1119. [CrossRef]

41. Toutirais, O.; Chartier, P.; Dubois, D.; Bouet, F.; Lévêque, J.; Catros-Quemener, V.; Genetet, N. Constitutive expression of TGF-bêta1, interleukin- 6 and interleukin- 8 by tumor cells as a major component of immune escape in human ovarian carcinoma. Eur. Cytokine Netw. 2003, 14, 246-255.

42. Feng, X.; Wang, C.-X.; Ou, Z.-Y. TGF- $\beta 1$ and IL-10 expression in epithelial ovarian cancer cell line A2780. Trop. J. Pharm. Res. 2015, 14, 2179-2185. [CrossRef]

43. Berg, D.T.; Gupta, A.; Richardson, M.A.; O'Brien, L.A.; Calnek, D.; Grinnell, B.W. Negative regulation of inducible nitric-oxide synthase expression mediated through transforming growth factor-beta-dependent modulation of transcription factor TCF11. J. Biol. Chem. 2007, 282, 36837-36844. [CrossRef]

44. Saad, A.F.; Hu, W.; Sood, A.K. Microenvironment and pathogenesis of epithelial ovarian cancer. Horm. Cancer 2010, 1, 277-290. [CrossRef] [PubMed]

45. King, M.-C.; Marks, J.H.; Mandell, J.B. New York Breast Cancer Study Group Breast and ovarian cancer risks due to inherited mutations in BRCA1 and BRCA2. Science 2003, 302, 643-646. [CrossRef]

46. Crijnen, T.E.M.; Janssen-Heijnen, M.L.G.; Gelderblom, H.; Morreau, J.; Nooij, M.A.; Kenter, G.G.; Vasen, H.F.A. Survival of patients with ovarian cancer due to a mismatch repair defect. Fam. Cancer 2005, 4, 301-305. [CrossRef]

47. Singer, G.; Oldt, R.; Cohen, Y.; Wang, B.G.; Sidransky, D.; Kurman, R.J.; Shih, I.-M. Mutations in BRAF and KRAS characterize the development of low-grade ovarian serous carcinoma. J. Natl. Cancer Inst. 2003, 95, 484-486. [CrossRef]

48. Zhang, D.; Piao, H.-L.; Li, Y.-H.; Qiu, Q.; Li, D.-J.; Du, M.-R.; Tsang, B.K. Inhibition of AKT sensitizes chemoresistant ovarian cancer cells to cisplatin by abrogating S and G2/M arrest. Exp. Mol. Pathol. 2016, 100, 506-513. [CrossRef]

49. Suzuki, N.; Yasui, M.; Geacintov, N.E.; Shafirovich, V.; Shibutani, S. Miscoding events during DNA synthesis past the nitration-damaged base 8-nitroguanine. Biochemistry 2005, 44, 9238-9245. [CrossRef]

50. Burney, S.; Caulfield, J.L.; Niles, J.C.; Wishnok, J.S.; Tannenbaum, S.R. The chemistry of DNA damage from nitric oxide and peroxynitrite. Mutat. Res. 1999, 424, 37-49. [CrossRef]

51. Grisham, M.B.; Jourd'heuil, D.; Wink, D.A. Review article: Chronic inflammation and reactive oxygen and nitrogen metabolism-implications in DNA damage and mutagenesis. Aliment. Pharmacol. Ther. 2000, 14 (Suppl. 1), 3-9. [CrossRef] [PubMed]

52. Jones, L.E.; Ying, L.; Hofseth, A.B.; Jelezcova, E.; Sobol, R.W.; Ambs, S.; Harris, C.C.; Espey, M.G.; Hofseth, L.J.; Wyatt, M.D. Differential effects of reactive nitrogen species on DNA base excision repair initiated by the alkyladenine DNA glycosylase. Carcinogenesis 2009, 30, 2123-2129. [CrossRef] [PubMed]

53. Parrish, M.C.; Chaim, I.A.; Nagel, Z.D.; Tannenbaum, S.R.; Samson, L.D.; Engelward, B.P. Nitric oxide induced S-nitrosation causes base excision repair imbalance. DNA Repair 2018, 68, 25-33. [CrossRef]

54. Chang, L.-C.; Huang, C.-F.; Lai, M.-S.; Shen, L.-J.; Wu, F.-L.L.; Cheng, W.-F. Prognostic factors in epithelial ovarian cancer: A population-based study. PLoS ONE 2018, 13, e0194993. [CrossRef]

55. Davidson, B.; Tropé, C.G. Ovarian cancer: Diagnostic, biological and prognostic aspects. Womens Health 2014, 10, 519-533. [CrossRef] 
56. Ezzati, M.; Abdullah, A.; Shariftabrizi, A.; Hou, J.; Kopf, M.; Stedman, J.K.; Samuelson, R.; Shahabi, S. Recent Advancements in Prognostic Factors of Epithelial Ovarian Carcinoma. Int. Sch. Res. Not. 2014, 2014, 953509. [CrossRef]

57. Xu, K.; Yang, S.; Zhao, Y. Prognostic significance of BRCA mutations in ovarian cancer: An updated systematic review with meta-analysis. Oncotarget 2017, 8, 285-302. [CrossRef]

58. Woopen, H.; Pietzner, K.; Richter, R.; Fotopoulou, C.; Joens, T.; Braicu, E.I.; Mellstedt, H.; Mahner, S.; Lindhofer, H.; Darb-Esfahani, S.; et al. Overexpression of the epithelial cell adhesion molecule is associated with a more favorable prognosis and response to platinum-based chemotherapy in ovarian cancer. J. Gynecol. Oncol. 2014, 25, 221-228. [CrossRef]

59. Shen, W.; Li, H.-L.; Liu, L.; Cheng, J.-X. Expression levels of PTEN, HIF-1 $\alpha$, and VEGF as prognostic factors in ovarian cancer. Eur. Rev. Med. Pharmacol. Sci. 2017, 21, 2596-2603.

60. Raspollini, M.R.; Amunni, G.; Villanucci, A.; Boddi, V.; Baroni, G.; Taddei, A.; Taddei, G.L. Expression of inducible nitric oxide synthase and cyclooxygenase-2 in ovarian cancer: Correlation with clinical outcome. Gynecol. Oncol. 2004, 92, 806-812. [CrossRef]

61. Ali-Fehmi, R.; Semaan, A.; Sethi, S.; Arabi, H.; Bandyopadhyay, S.; Hussein, Y.R.; Diamond, M.P.; Saed, G.; Morris, R.T.; Munkarah, A.R. Molecular typing of epithelial ovarian carcinomas using inflammatory markers. Cancer 2011, 117, 301-309. [CrossRef]

62. Engels, K.; du Bois, A.; Harter, P.; Fisseler-Eckhoff, A.; Kommoss, F.; Stauber, R.; Kaufmann, M.; Nekljudova, V.; Loibl, S. VEGF-A and i-NOS expression are prognostic factors in serous epithelial ovarian carcinomas after complete surgical resection. J. Clin. Pathol. 2009, 62, 448-454. [CrossRef]

63. Saied, E.M.; El-Etreby, N.M. The role and prognostic value of inducible nitric oxide synthase (iNOS) and interleukin-33 (IL-33) in serous and mucinous epithelial ovarian tumours. Ann. Diagn. Pathol. 2017, 27, $62-68$. [CrossRef]

64. Li, L.; Zhu, L.; Hao, B.; Gao, W.; Wang, Q.; Li, K.; Wang, M.; Huang, M.; Liu, Z.; Yang, Q.; et al. iNOS-derived nitric oxide promotes glycolysis by inducing pyruvate kinase M2 nuclear translocation in ovarian cancer. Oncotarget 2017, 8, 33047-33063. [CrossRef]

65. Anttila, M.A.; Voutilainen, K.; Merivalo, S.; Saarikoski, S.; Kosma, V.-M. Prognostic significance of iNOS in epithelial ovarian cancer. Gynecol. Oncol. 2007, 105, 97-103. [CrossRef]

66. Ozel, E.; Peştereli, H.E.; Simşek, T.; Erdoğan, G.; Karaveli, F.S. Expression of cyclooxygenase-2 and inducible nitric oxide synthase in ovarian surface epithelial carcinomas: Is there any correlation with angiogenesis or clinicopathologic parameters? Int. J. Gynecol. Cancer 2006, 16, 549-555. [CrossRef]

67. Martins Filho, A.; Jammal, M.P.; de Castro Côbo, E.; Silveira, T.P.; Adad, S.J.; Murta, E.F.C.; Nomelini, R.S. Correlation of cytokines and inducible nitric oxide synthase expression with prognostic factors in ovarian cancer. Immunol. Lett. 2014, 158, 195-199. [CrossRef] [PubMed]

68. Ushijima, K. Treatment for recurrent ovarian cancer-at first relapse. J. Oncol. 2010, 2010, 497429. [CrossRef] [PubMed]

69. Tapia, G.; Diaz-Padilla, I. Molecular Mechanisms of Platinum Resistance in Ovarian Cancer. In Ovarian Cancer-A Clinical and Translational Update; Intech Open: London, UK, 2013.

70. Brasseur, K.; Gévry, N.; Asselin, E. Chemoresistance and targeted therapies in ovarian and endometrial cancers. Oncotarget 2017, 8, 4008-4042. [CrossRef]

71. Turchi, J.J. Nitric oxide and cisplatin resistance: NO easy answers. Proc. Natl. Acad. Sci. USA 2006, 103, 4337-4338. [CrossRef]

72. Kielbik, M.; Klink, M.; Brzezinska, M.; Szulc, I.; Sulowska, Z. Nitric oxide donors: Spermine/NO and diethylenetriamine/NO induce ovarian cancer cell death and affect STAT3 and AKT signaling proteins. Nitric Oxide 2013, 35, 93-109. [CrossRef] [PubMed]

73. Singh, S.; Gupta, A.K. Nitric oxide: Role in tumour biology and iNOS/NO-based anticancer therapies. Cancer Chemother. Pharmacol. 2011, 67, 1211-1224. [CrossRef] [PubMed]

74. Sinha, B.K. Nitric Oxide: Friend or Foe in Cancer Chemotherapy and Drug Resistance: A Perspective. J. Cancer Sci. Ther. 2016, 8, 244-251. [CrossRef]

75. Perrotta, C.; Cervia, D.; Di Renzo, I.; Moscheni, C.; Bassi, M.T.; Campana, L.; Martelli, C.; Catalani, E.; Giovarelli, M.; Zecchini, S.; et al. Nitric Oxide Generated by Tumor-Associated Macrophages Is Responsible for Cancer Resistance to Cisplatin and Correlated With Syntaxin 4 and Acid Sphingomyelinase Inhibition. Front. Immunol. 2018, 9, 1186. [CrossRef] 
76. Leung, E.L.; Fraser, M.; Fiscus, R.R.; Tsang, B.K. Cisplatin alters nitric oxide synthase levels in human ovarian cancer cells: Involvement in p53 regulation and cisplatin resistance. Br. J. Cancer 2008, 98, 1803-1809. [CrossRef] [PubMed]

77. Yu, Y.; Xie, Q.; Liu, W.; Guo, Y.; Xu, N.; Xu, L.; Liu, S.; Li, S.; Xu, Y.; Sun, L. Increased intracellular Ca ${ }^{2+}$ decreases cisplatin resistance by regulating iNOS expression in human ovarian cancer cells. Biomed. Pharmacother. 2017, 86, 8-15. [CrossRef]

78. Belotte, J.; Fletcher, N.M.; Awonuga, A.O.; Alexis, M.; Abu-Soud, H.M.; Saed, M.G.; Diamond, M.P.; Saed, G.M. The role of oxidative stress in the development of cisplatin resistance in epithelial ovarian cancer. Reprod. Sci. 2014, 21, 503-508. [CrossRef]

79. Malone, J.M.; Saed, G.M.; Diamond, M.P.; Sokol, R.J.; Munkarah, A.R. The effects of the inhibition of inducible nitric oxide synthase on angiogenesis of epithelial ovarian cancer. Am. J. Obstet. Gynecol. 2006, 194, 1110-1116, discussion 1116-1118. [CrossRef] [PubMed]

80. Zhao, L.; Yu, C.; Zhou, S.; Lau, W.B.; Lau, B.; Luo, Z.; Lin, Q.; Yang, H.; Xuan, Y.; Yi, T.; et al. Epigenetic repression of PDZ-LIM domain-containing protein 2 promotes ovarian cancer via NOS2-derived nitric oxide signaling. Oncotarget 2016, 7, 1408-1420. [CrossRef]

81. Saed, G.M.; Ali-Fehmi, R.; Jiang, Z.L.; Fletcher, N.M.; Diamond, M.P.; Abu-Soud, H.M.; Munkarah, A.R. Myeloperoxidase serves as a redox switch that regulates apoptosis in epithelial ovarian cancer. Gynecol. Oncol. 2010, 116, 276-281. [CrossRef] [PubMed]

82. Son, K.K.; Hall, K.J. Nitric oxide-mediated tumor cell killing of cisplatin-based interferon-gamma gene therapy in murine ovarian carcinoma. Cancer Gene Ther. 2000, 7, 1324-1328. [CrossRef]

83. Xu, W.; Liu, L.; Charles, I.G. Microencapsulated iNOS-expressing cells cause tumor suppression in mice. FASEB J. 2002, 16, 213-215. [CrossRef]

84. Hendren, S.K.; Prabakaran, I.; Buerk, D.G.; Karakousis, G.; Feldman, M.; Spitz, F.; Menon, C.; Fraker, D.L. Interferon-beta gene therapy improves survival in an immunocompetent mouse model of carcinomatosis. Surgery 2004, 135, 427-436. [CrossRef]

85. Trinh, B.; Ko, S.Y.; Haria, D.; Barengo, N.; Naora, H. The homeoprotein DLX4 controls inducible nitric oxide synthase-mediated angiogenesis in ovarian cancer. Mol. Cancer 2015, 14, 97. [CrossRef]

(C) 2019 by the authors. Licensee MDPI, Basel, Switzerland. This article is an open access article distributed under the terms and conditions of the Creative Commons Attribution (CC BY) license (http://creativecommons.org/licenses/by/4.0/). 